\title{
SPLENECTOMY AND EXPERIMENTAL INFECTION OF MICE BY A VIRULENT STRAIN OF TRYPANOSOMA CRUZI
}

\author{
Humberto Menezes (*)
}

Splenectomy seems to increase susceptibility of mice to a further infection with a virulent strain of Trypanosoma cruzi.

Parasitemia increases with splenectomy and the sooner the infection follows the operation, the greater the parasitemia.

The mortality rate seems to have not been influenced by splenectomy.

\section{INTRODUCTION}

The effects of splenectomy in infections diseases, especially in those produced by protozoa, are still a matter of dispute (12).

In some people's opinion animals previously splenectomized are more susceptible to certain parasitic and bacterial infections than are normal animals $(1,4,5,6,13,15$ ), while others claim that splenectomy has no effects on the development of a fur.ther infection $(3,11,13,14)$.

Being interested in the consequences of splenectomy in experimental trypanosomiasis cruzi in mice, we performed some experiments hoping to shed some light on this controversial question.

\section{MATERIAL AND METHODS}

1 - Two groups of 24 and 10 male white mice, each, with a mean body weight of $10 \mathrm{~g}$. were splenectomized under ether anesthesia.

6 days later the animals of the first group were infected with the virulent $Y$ strain of Trypanosoma cruzi, maintained in mice. At the same time a control group of 21 mice was infected with an equal number of infective flagellates.

We injected 50 flagellates per gram of body weight, by intraperitoneal route.

The parasites were obtained by bleeding mice on the 8th day of infection.

The second group of 10 splenectomized animals was kept as control over the cperation.

2 - Twelve male white mice with the same characteristics of the above group were splenectomized under the same conditions. Twelve days later these animals and 10 of a control group were infected as the preceding groups.

3 - Seven male white mice with $10 \mathrm{~g}$. body weight were splenectomized under ether anesthesia. After 30 days these an:mals and 7 of a control group were infected as had been the above mentioned groups.

Parasitemia by the Pizzi-Brener technique (2) was done on the $8^{\text {th }}, 15^{\text {th }}$ and $30^{\text {th }}$ day after the infection. 
TABLE 1

INFECTION 6 DAYS AFTER SPLENECTOMY

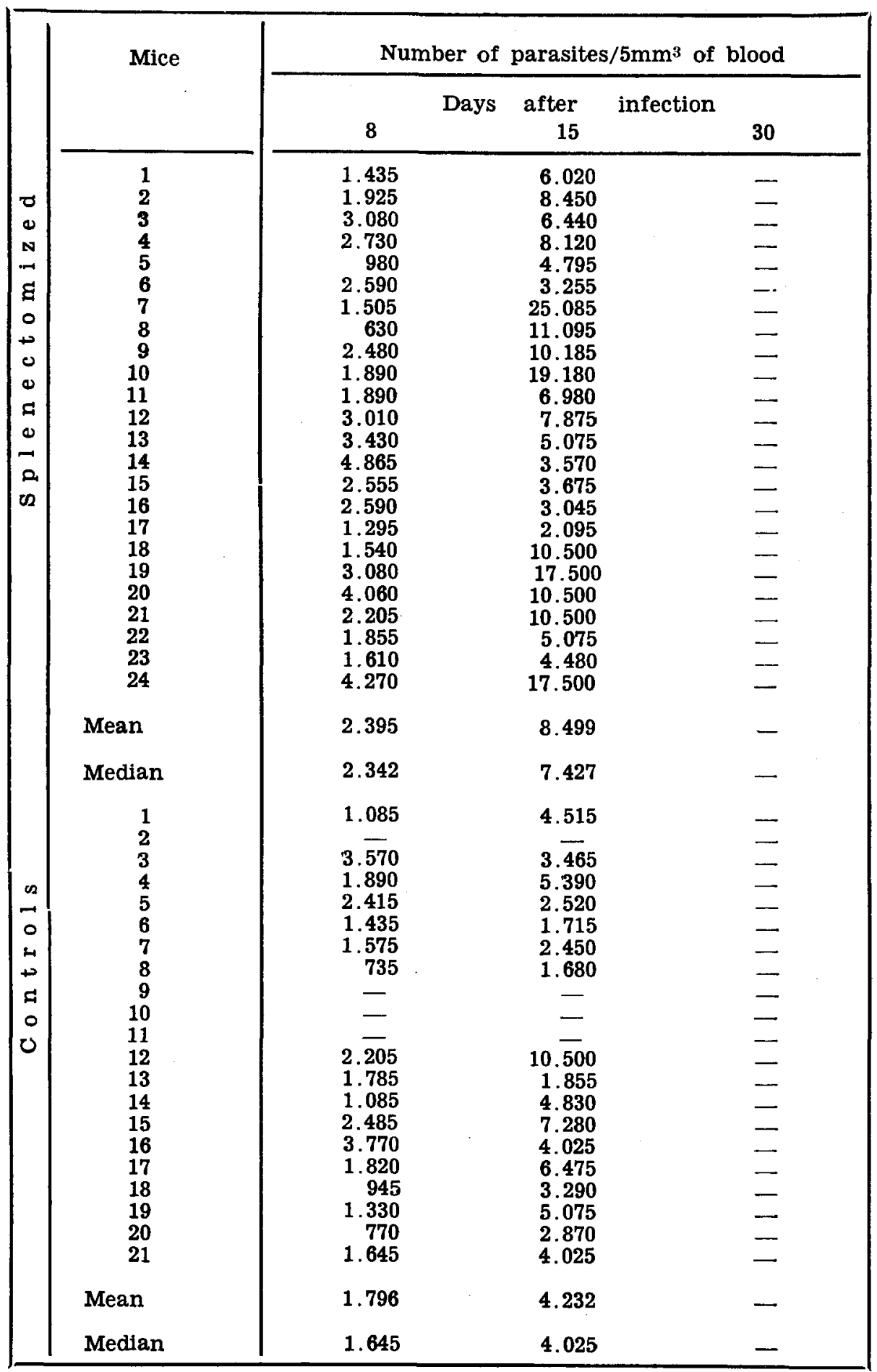


TABLE 2

INFECTION 12 DAYS AFTER SPLENECTOMY

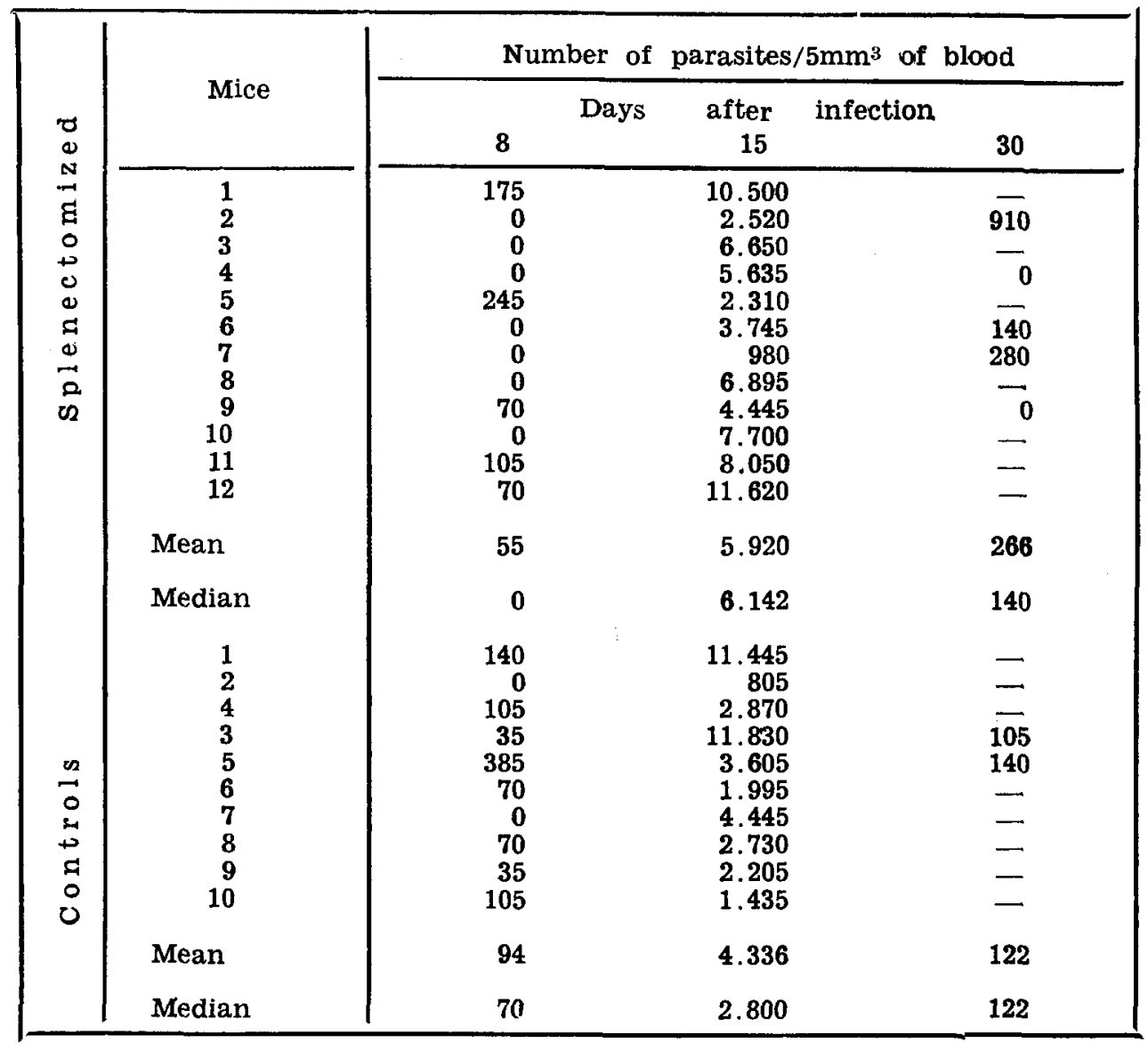


TABLE 3

INFECTION 30 DAYS AFTER SPLENECTOMY

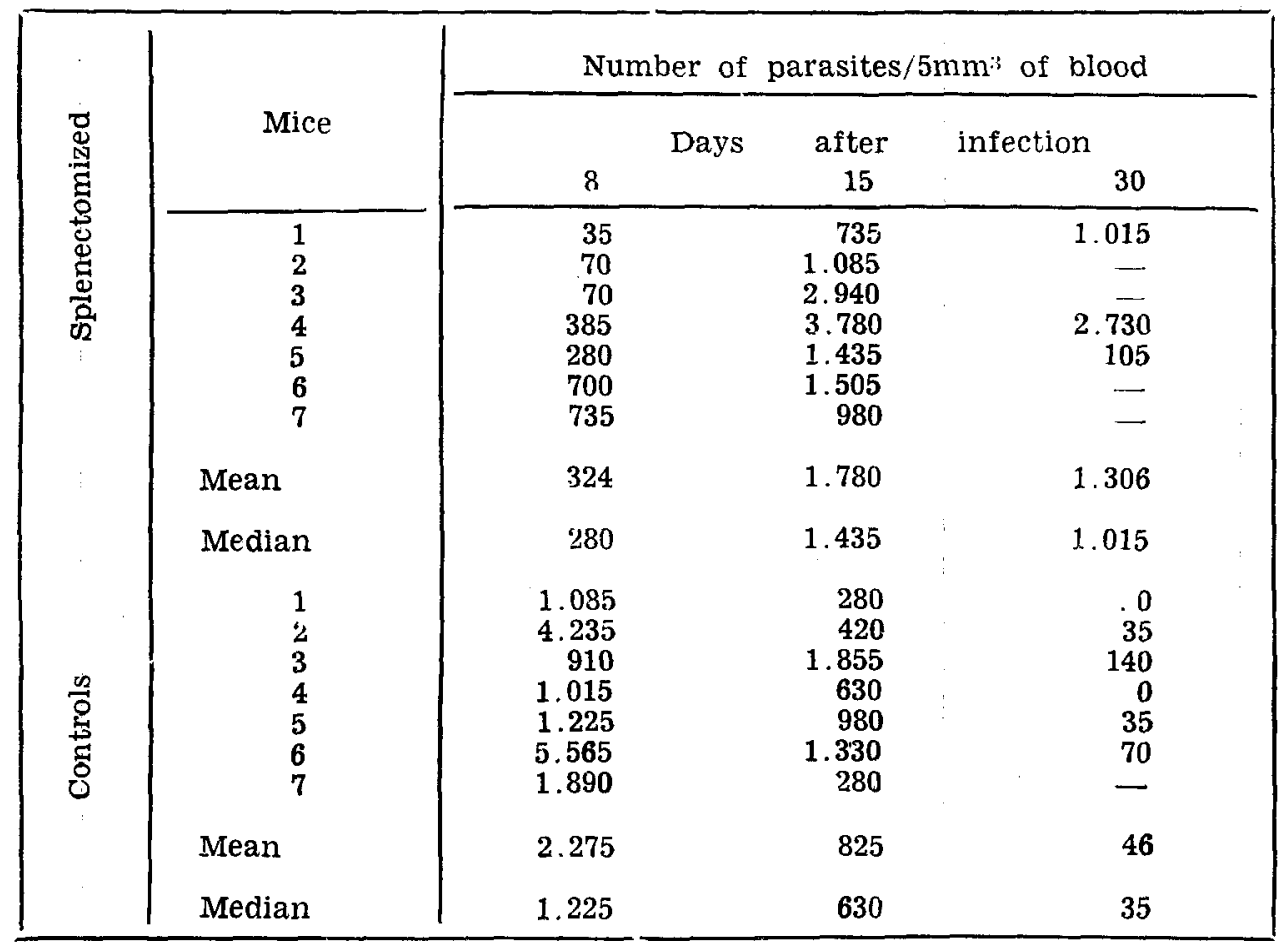




\section{GRAPH I}

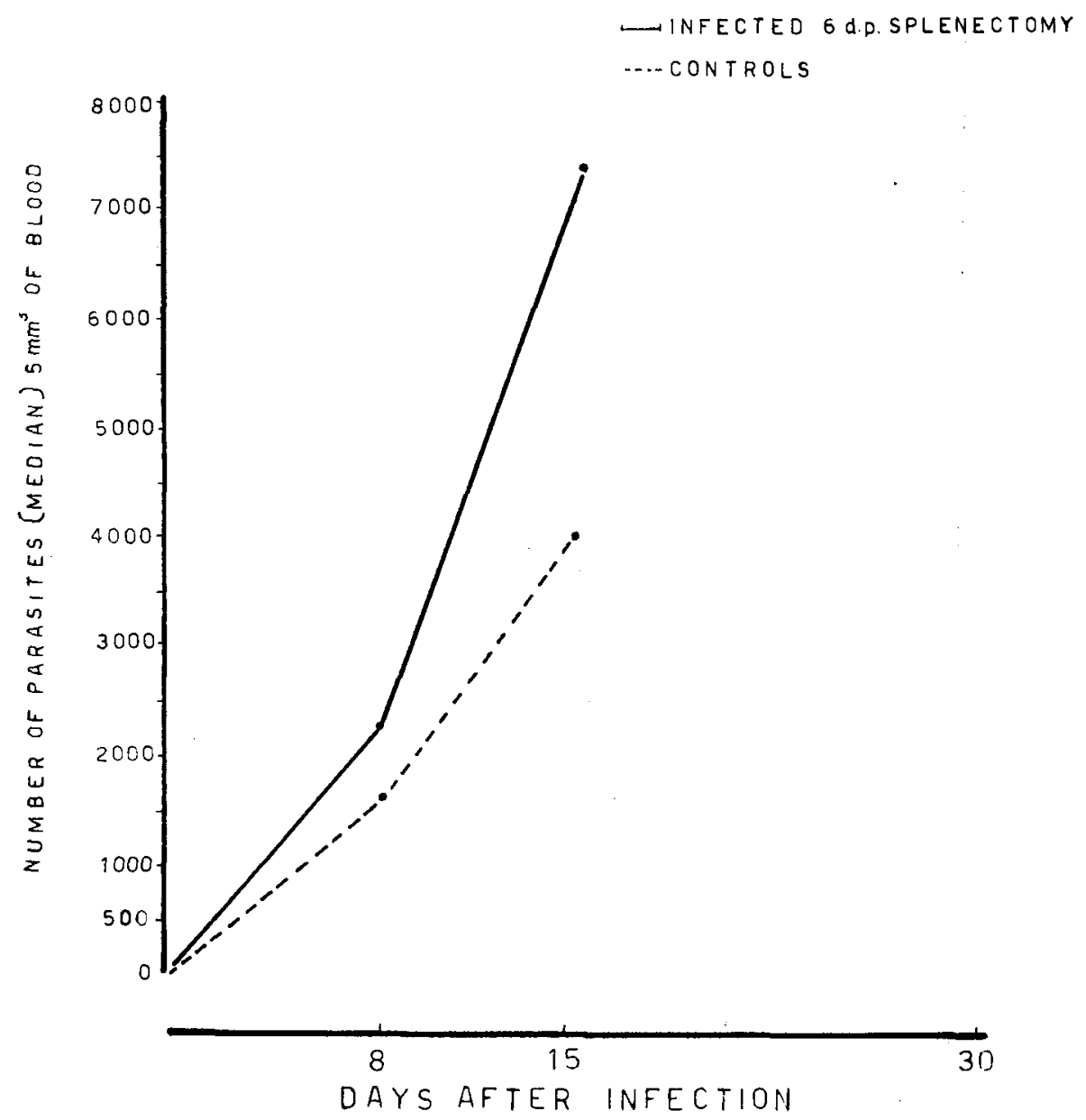


GRAPH II

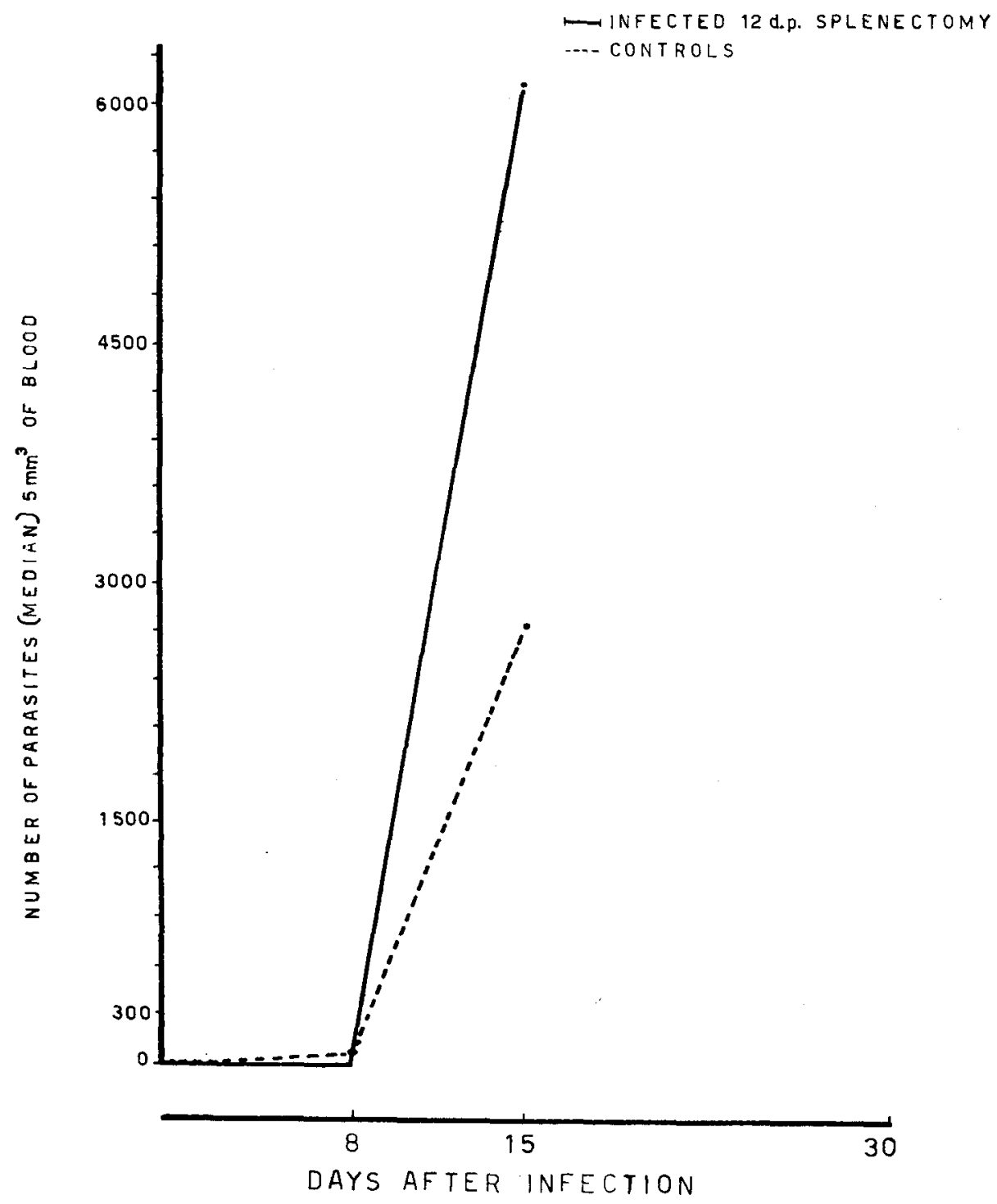


— INFECTED 30 d.p.SPLENECTOMY

.... CONTROLS

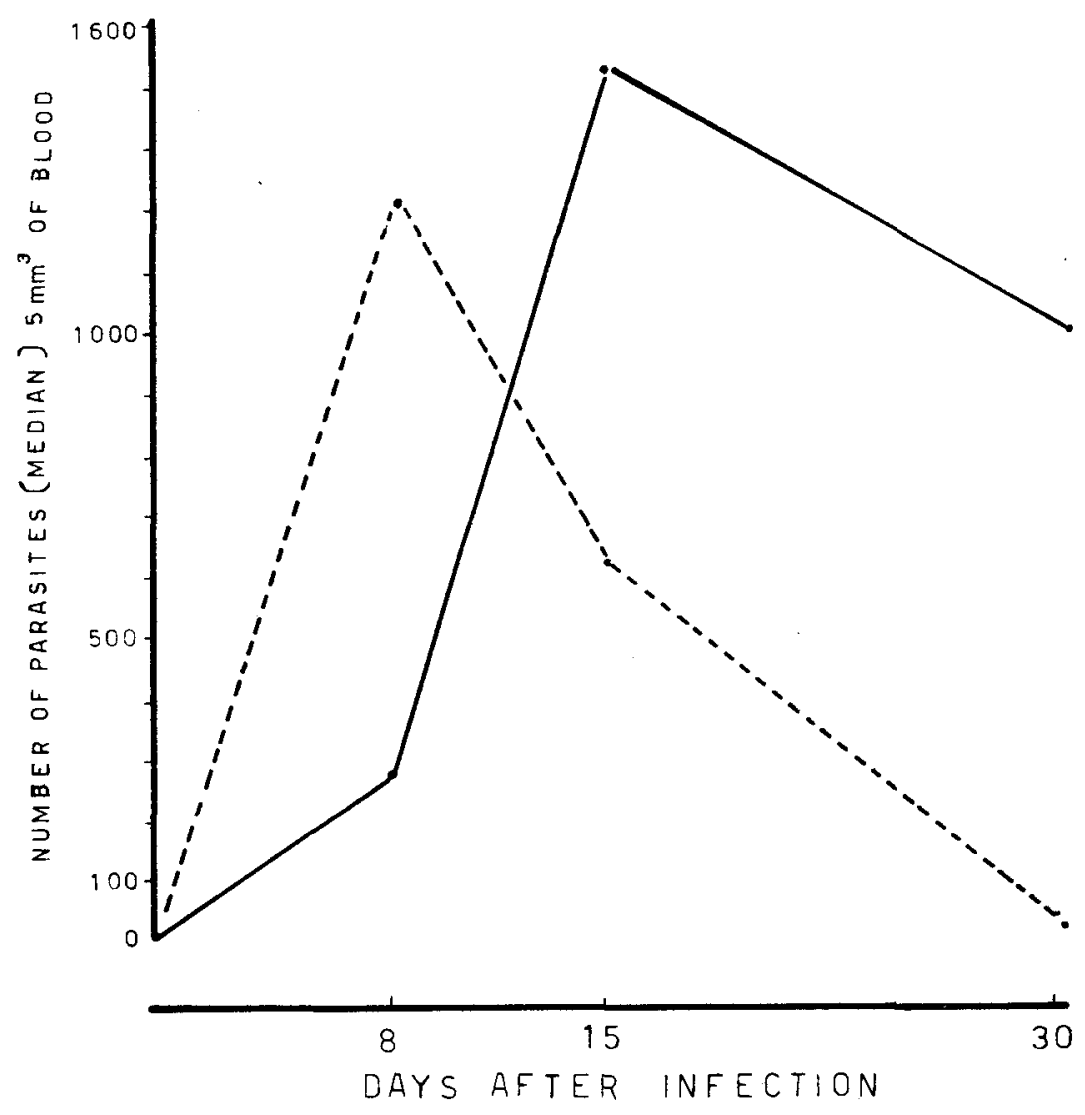




\section{RESULTS}

As shown by the Tables 1, 2 and 3 and Graphs I, II and III, splenectomy generaly increases parasitemia of white mice submitted to an infection with a low inoculum of virulent $\mathrm{Y}$ strain Trypanosome cruzi.

This increase was almost the same in the three splenectomized groups, particularly at the peak of the parasitemia $\left(15^{11}\right.$ day), as compared with the respective ccntrol group.

Our results are inconclusive with respect to the surviving percentage of the splenectomized mice in relation to the control animals but it seems that no significant difference exists between them:

$20 \%$ of the animals of the splenectomy control group died in the 30 days period of the experiment

\section{COMMENTS AND CONCLUSIONS}

It is almost impcssible to make a comparison between the several works done on the subjest of splenectomy and infection because the techniques and material used were quite different in each case.
Using a standardized method, and mice of the same age, body weight, sex and strain we could demonstrate, varying only the size of the inoculum, that splenectomy increases the susceptibility of mice to a further infection with virulent Trypanoso$m a$ cruzi strain as expressed by an increased parasitemia.

The percentage of the animals surviving 30 days seems not to be influenced either by the splenectomy or by the number of injected flagellates, but the time elapsed between the operation and the infection and/or the age of the animals reduces the number of parasites in the blood stream.

Even in these cases in which the infection was delayed in relation to the splenectomy and the parasitemia was lower than in the more precocious infection, a higher parasitemia persisted among the splenectomized mice.

The hyperplasia of the remaining Reticulo-endothelial-system (RES) is perhaps responsable for this, since in cases in which splenectomy plus the blockade of the RES (1) or simply the blockade of this system was done (5), susceptibility to trypancsoma infection has been increased.

\section{RESUMO}

Esplenectomia ein canundongos jovens aumenta sensivelmente a parasitemia daqueles submetidos posteriormente a uma infecção com um baixo inoculo de Trypanoscma cruai, porém não parece influenciar a taxa de mortalidade dos animais, pelo menos dentro do período considerado (30 dias).

o número de parasitas na corrente sanguinea foi tanto maior quanto mais jovens eram os camundongos e quanto mais próxima foi a infecção da esplenectomia

\section{REFERENCES}

1. AMAKO, T. $\mathrm{H} . \quad \ldots$ Beitrage zur Kenntnis des Schutzkraft der Milz und den Retikuloendothelial - Systems gegen eine Infektion des organismus durch Spircshaeta Duttoni und Trypanosoma gambiense. Zbl Bakter. 116: 280-284, 1930.

2. BRENER, Z - Contribuição ao estudo da terapêtica experimental da Doença de Chagas. Tese. Fac. Farm. Odont. Univ. Minas Gerais. B. Horizonte, 1961.

3. DIAS, E. - Estudos sôbre o Schizotrypanum cruzi. Mem. Inst. Oswaldo Cruะ. 28: 1-110, 1934
4. GOBLE. F. C. \& SINGER, I - The reticulo-endothelial system in expe.. rimental malaria and trypanosomiasis. Ann. N. York Acad. Sc. 88: 149171,1960 .

5. GOBLE, F. C. \& BOYD, J. L. Reticulo-endothelial blockade in Experimental Chagas' disease. J. Parasit: 46: 44,1960

6. KOFIDE, C. A. \& DONAT, F. - The experimental transter of irypanosoma cruzi from naturally infected Triatoma proctata. Proc. Soc. Exp. Biol. \& Med. 30: 489, 1933. in DIAs op. cit. 
7. MENEZES, $\mathrm{H}$. - $\mathrm{O}$ emprègo de adjuvantes na vacinação de camundongos com Trypanosoma cruzi - II. Rev. Bras. Med. 22: 536-538, 1965.

8. MENEZES, H. - A importância do fator sexo na parasitemia e mortalidade de camundongos albinos com infecção experimental pelo $T$. cruzi. O Hospital 70: 991-994, 1966.

9. MENEZES, $H$. - The effect of phenolated "vaccines" against experimental Trypanosoma cruzi infection in mice. Rev. Soc. Bras. Med. Tiop. 2: $59-66,1968$.

10. MENEZES, $\mathbf{H}$. - Protective effect of an avirulent (cultivated) strain of Trypanosoma cruzi against experimental infection in mice. Rev. Inst. Med. Trop. São Paulo. 10: 1-4, 1968

11. NIESCHULZ, O \& WAWO-ROENTOE, F. K. - Über den Einfluss der Milz exstirpation bei Infektionen mit Trypanosoma gambiense und Schizotrypanum cruzi. Z. Immun. Forsch. u. exper. Therap. 65: 312-317, 1930.

12. NOORUDDIN \& AHMED, S. S. - The effects of splenectomy on parasitic infections and the rôle of the spleen in filariasis - A brief appraisal of our present knowledge. J. Trop. Med. \& Hyg. 70: 229-232, 1967.

13. PERLA, D. \& MARMORSTON, J ... The spleen and resistance. Bailliere, Tindall \& Cox. London. 1935, in NOORUDDIN \& AHMED op. cit.

14. PIZZI, T. -.- Immunologia de la enfermedad de Chagas. Boll. Of. Sanit. Panamer. 51: 450-464, 1961.

15. REGEDANZ, P. - Der Verlauf der Infektion mit Schizotrypanum cruzi (Chagas) bei jungen Ratten und übei die Unempfänglichkeit erwarhsener Ratten für Schizotrypanum. Zbl. Bakter. 116: 256-264, 1930

16. WHITACKER, A. N. - The effect of previous splenectomy on the course of pneumoccccal bacteremia in mice. .T. Path. \& Bact. 95: 357-376, 1968. 